International Journal of Heritage, Tourism and Hospitality Vol. (14), No. (1), June, 2020

\title{
New Kingdom Textile Decoration Techniques and Significance: Evidences from the Egyptian Textile Museum in Cairo
}

\author{
Osama Ibrahim \\ Faculty of Tourism and Hotels- Fayoum University
}

\begin{abstract}
Textile decorations spread all over Egypt during the New Kingdom not only due to the prosperity of the country's economy but also the expansion of the Egyptian Empire and the influence on textile decorations by foreign weavers. mainly Syrian, on Egyptian clothes is powerful. The present study aims to investigate the fabric's decoration and the Egyptological analysis of three textile pieces preserved in the 'Egyptian Textile Museum' in Cairo that carry religious Neither surveying nor comparing the decoration techniques of the New Kingdom has been done by author. This paper aims to compare the textile decoration techniques occurred in ancient Egyptian New Kingdom depending on the decorated pieces in the newly inaugurated "Azhar Textile Museum Significance. The paper studies the morphological appearance of the pieces through visual examination of fibers by light microscopic to reveal what decoration techniques were used. Then it analyzes the religious significance of the decorations through analyzing scenes and texts they form. Eventually, technical setting about the techniques of the fabric decoration is delivered, bringing into argumentation the religious role of these pieces revealed from their decorations. The paper concluded that three different decoration techniques occurred in New Kingdom clothes encompassing Weft looping, Tapestry Weave, and coloring. It investigated reasons behind the spread of these specific techniques. Coloring techniques of the three studied pieces are also analyzed. Moreover, major similarities and differences among decoration and coloring techniques have been resulted.
\end{abstract}

Keywords: Decoration Technique, Religious Significance, New Kingdom, Textile.

\section{Introduction}

This article contributes to the knowledge of some pieces of the Pharaonic collection of the Egyptian Textile Museum ${ }^{1}$, located in Al-Moez Ldin Allah Street in El-Gamaleya district in Cairo. It houses a rare collection of textile pieces including cloths, coverings, blankets, bandages, etc discovered in Ancient Egyptian tombs and temples. These pieces reflect different decoration techniques and religious significance. The museum is divided into three sections (Pharaonic, Coptic, and Islamic) that encompasses 450 textile pieces.

This paper investigates the only decorated textile pieces in the Pharaonic section with scenes and/or texts. The first piece (no.71) was obtained from Deir El-Madinah, Luxor, and can be dated to the Ramesside Period, the reign of the Ramesses III, the second king of the $20^{\text {th }}$ Dynasty (ca.1186-1155 BC) due to the style of iconography including slim human representation, cloths style, and hair wig. The other two pieces (nos.81\& 82) were discovered in the tomb of Thutmosis IV in Luxor. The pieces bear Thutmosis IV's titles, the 8th King of the 18th Dynasty (ca. 1401 $1391 \mathrm{BC})$.

The Fabric decorations of the three archaeological textile samples studied reveal that the technical characteristics used including: tapestry plain weave and coloring. They also explain some important implications of particular religious evidences of the three samples. In the first piece, the fabric decorations manifest a scene of a man and his wife worship Taweret Spsyt $n b t$

${ }^{1}$ The Textile Museum itself was originally a Sabil of Mohamed Ali Pasha, built in 1822 as ongoing charity for the spirit of his father. 
$m^{3} t$ and in the other two pieces Thutmosis IV venerated his grandfather Thutmosis III by performing the opening of the mouth ceremony to him.

In the Predynastic, the first Egyptian fabrics came from the Neolithic period around 5.500 BC. When flax was cultivated and linen was produced ${ }^{2}$ as evident from the discovery of a textile fragment at the north of Qarun Lake in the Fayoum ${ }^{3}$. Also, from the ceramic plate discovered in the tomb no.3802 of an unknown woman in Badari, dated back to around 4.000 BC, on which a representation of horizontal loom can be seen. Therefore, plants form the oldest basic fiber used in the textile industry in ancient Egypt and, notably, the production of linen fabrics in horizontal looms is assured in the Egyptian Prehistory ${ }^{4}$.

Starting from the Old Kingdom, specialized workshops for textile production were operated by professional women weavers. This means that weaving profession was purely feminine ${ }^{5}$ - until the New Kingdom when male weavers appeared for the first time - and also practiced by all social classes from royal harem to average women who weave at home ${ }^{6}$.

The New Kingdom witnessed both the abundance of textile production, the diversity of decoration and coloring ${ }^{7}$, and the use of vertical looms ${ }^{8}$. One of the simplest decoration techniques extensively used in ancient Egypt on vertical looms especially during the New Kingdom was "Tapestry plain weave'9. It was weaved of two or more different colors in unexpanded wefts on the loom width ${ }^{10}$. Another important technique that was copied from Asian textile samples or learnt from foreign craftsman employed in weaving shops is 'warp weave' such as the collection of textile pieces discovered in the tomb of Tutankhamen ${ }^{11}$. Furthermore, a third decoration technique in which wefts expanded on the textile surface to form what look like closed or open loops is called 'weft looping'12. This technique, which was first appeared during the $11^{\text {th }}$ Dynasty, is characterized by using a stick on which weft threads are wrapped to get equal length for the fur ${ }^{13}$.

Worth-mentioning that the majority of ancient Egyptian textiles made out of linen for different reasons: It highly absorbs moisture which is appropriate for the Egyptian hot weather; and it represents purity according to ancient Egyptians beliefs, therefore, the corps of god Osiris is

2 Allgrove-Mcdowell, J. Industries of the Near East and Europe in prehistory, Ancient Egypt, 5000-332 BC. In David T. J. (Ed.), the Cambridge History of Western Textiles. United Kingdom: Cambridge University Press, (2003): 30; Landi, S. The Textile Conservator's manual, London, 1985: 146.

${ }^{3}$ Hall, Rosalind. Egyptian textiles. United Kingdom: Shire Publications LTD, 2001: 9.

4 Allgrove-Mcdowell, Industries of the Near East and Europe in prehistory: 34; Hall, Egyptian textiles: 15; Barber, Elizabeth. Prehistoric Textiles. Princeton: Princeton University Press, 1991: 82.

${ }^{5}$ Eric, B. the Book of Looms. New York, 1998: 10.

6 Fischer, H. G. Egyptian women of the old kingdom. And of the Heracleopolitan Period. New York: The Metropolitan Museum of Art, 2000: 45.

${ }^{7}$ Depas, S. Weaving and Tapestry Art in fiber. Macmillan publish Go, INC, New York, 1989: 61.

${ }^{8}$ Harries, J. 5000 years of Textile. British Museum, London, 2004: 26.

9 Thompson G.W. History of Tapestry from earliest until the present day. New York, 1977: 6; Russell, C. K. Tapestry Handbook. Schiffer Publication Ltd, 2007: 13.

${ }^{10}$ Barber, E.J.W. New Kingdom Egyptian Textile: Embroidery V.S Weaving. AJA 86, 1982: 442-445.

${ }^{11}$ Harries, J. 5000 Years of Textile. British Museum, London, 2004: 23.

12 Harries, 5000 Years of Textile: 51.

13 Bellinger, L. and Batigne, R. The Significance and Technical Analysis of Ancient Textiles as Historical Documents. PAPS, 97, 1953: 670-680; Bellinger, L. Textile Analysis: Developing Techniques in Egypt and Near East. vol.V, Washington, 1957: 66. 
wrapped in linen ${ }^{14}$. Moreover, textile products in Ancient Egypt varied widely and indicated cultural codes that bear distinctive social meanings and nonverbal communication elements within the Egyptian society ${ }^{15}$.

\section{Pieces Decoration Techniques Analyses}

\section{Technical Macroscopic Observations}

The set of two samples from the decoration fibers of the three pieces under investigation were analyzed in the Central Laboratories Sector of the Egyptian Mineral Resources Authority at the Ministry of Petroleum in Dokki, Giza so as to allow a clear macroscopic observation. The Scanning Electron Microscope (SEM) photographs were carried out for 2 samples using SEM Model Philips XL 30 attached with EDX Unit, with accelerating voltage $30 \mathrm{~K}$.V., magnification 10x up to $400.000 \mathrm{x}$ and resolution for W. $(3.5 \mathrm{~nm})$ in order to identify the fibers with which they had been made, the technical characteristics of the yarns, and the density of the tissue. The description of the yarns was made considering the number of units or ends that compose it, and the direction and degree of twist. To make fibers of a discreet length - such as linen or cotton become a continuous beam suitable for knitting, it is necessary to twist them. The torsion of the fibers can be done from right to left, which generates a diagonal in S, or in the opposite direction, generating a diagonal in $\mathrm{Z}^{16}$.

The use of the loom implies the orthogonal cross-linking of two yarn systems, warp (vertical) and weft (horizontal) ${ }^{17}$. Through the alternating lifting of warp yarns and the horizontal movement of the weft passes, these units give rise to a textile, which constitutes a woven structure $^{18}$.

Results revealed that all the tissues analyzed would have been made in vertical loom, from a technical perspective. The warp and weft raw material of the sample of the piece no.81 is linen and the yarns correspond to S-twisted ends, with a strong degree of torsion and a very fine thickness (30-35). By means of the loom weave, a tissue was produced, with a density of 13 warps and 11 wefts per $\mathrm{cm}^{2}$. The yarns of the $2^{\text {nd }}$ sample (piece no.71) correspond to linen ends, with twist $S$, with strong twist and very fine thickness (30-35). The elaboration technique was the loom with a density of 26 warps and 12 wefts per $\mathrm{cm}^{2}$ (see fig.1).

According to the analysis carried out on the two samples, it is determined that the raw material used corresponds exclusively to linen. It could also be confirmed that all fabrics was through the use of the loom, very fine threads were used, spinning technique $S$ was also evident, with a strong degree of twisting in all samples. Therefore, it is obvious that the decoration technique used is tapestry plain weave ${ }^{19}$. However, the variations in both the thickness of the yarns and the density of the fabric, could correspond to technical differences according to the type of loom used, as well as the chronological difference.

${ }^{14}$ Crowfoot, G.M., Textiles, Basketry and Mats: A history of Technology, I. Oxford, 2001: 373; Yvonne, H. Decoration in Egyptian Tombs of the Old Kingdom, London, 1987: 114-115; Salmon, L. Textiles: Egypt's Golden age, the Art of Living in the New kingdom. Museum of fine art, Boston, 1982: 183.

15 Hall, Egyptian textiles: 15-18.

${ }^{16}$ Emery, I. The primary structures of fabrics. An Illustrated Classification. Washington, D.C.: Watson-Guptill Publications, Whitney Library of Design, the Textile Museum, 1995: 13.

17 Kourkoumelis, N. Physicochemical Characterization of Thermally Aged Egyptian Linen Dyed with Organic Natural Dyestuffs. Applied Physics, 112(2), 2013: 469-478.

${ }^{18}$ Eric, the Book of Looms: 8-9.

${ }^{19}$ Vogelsang-Eastwood, G. Textiles: Ancient Egyptian Materials and Technology. In Paul T. Nicholson \& Ian Shaw (Eds.), United Kingdom: Cambridge University Press, 2000: 296; Hilary, C. Simple Weaving. Studio vista, London, 1973: 52-53. 
Figure 1: Microscopic Examination of Archaeological Samples (Piece 71 left and Piece 81 right)
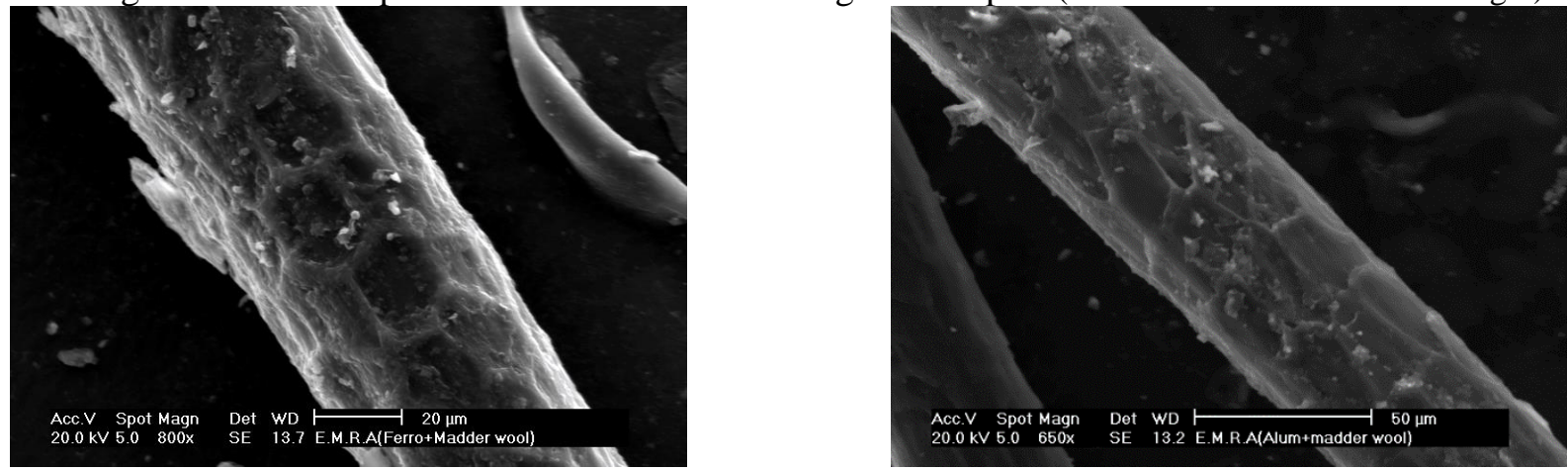

\section{Coloring/Dying Techniques}

The earliest evidence of dyed materials in Egypt is a mat from the Predynastic period whose edge is red ${ }^{20}$. Moreover, mummy bindings that date back to around $2.500 \mathrm{BC}$. Revealed the advance analyzed dyeing of iron buff and non-saffron yellow ${ }^{21}$. However, only a few examples of dyed clothes came from periods preceding the New Kingdom. This could be explained that dyeing was not extensively practiced before the New Kingdom due to the fact that linen is extremely difficult to dye. In the New Kingdom, though, the frequency of using dyeing and the combination of colors used on the same cloth clearly indicate a mastery of this $\operatorname{art}^{22}$.

A great number of dyed textiles with many colors was investigated. Indigo, which was probably extracted from woad or indigofera argentea, was found on linen threads of a princess's costumes which dates back to $1000 \mathrm{BC} .^{23}$. Also, madder was found on a belt fragment from the tomb of Thutankhamon ( $\mathrm{ca} .1350 \mathrm{BC}$. $)^{24}$. Worth-mentioning, all the colors used were natural and perhaps of local origin, except probably for madder plant which was imported from Asia and then planted in Egypt during the New kingdom ${ }^{25}$. The ancient Egyptians used to extract red color from the roots of madder which contain the coloring substance called Alizarin ${ }^{26}$. Also, a 21st Dynasty piece of cloth contains the red color of the safflower and henna ${ }^{27}$. Furthermore, hematite, red iron oxide, was used to extract red color since prehistory ${ }^{28}$.

The blue color was perhaps extracted from indigofera tinctorial plant, or isatis tinctorial plant, or, as mentioned in the texts of Dendera and Edfu temples, from Water Hyacinth and Madder. Furthermore, texts from Dendera explained the stages of processing dyes from colorless to red, to orange, then to green, and finally to blue ${ }^{29}$. Worth-mentioning, the degree of each two colors was technically changing according to the mordents ${ }^{30}$.

${ }^{20}$ Forbes, R. J. Studies in Ancient Technology. vol.IV, Leiden, 1956: 12.

${ }^{21}$ Hubner, J. The Examination of Some Ancient Egyptian Textiles, Journal of the Society of Dyers and Colouris, 25, 1909: 223-226.

${ }^{22}$ Pfister, R. Les Textiles du Tombeau de Tutankhamen. in: Revue des Arts Asiatiques II, 1937: 207-218; VogelsangEastwood, G. Egyptian Dyes and Colors. in: Dyes on historical and archaeological Textiles, Summery of $3^{\text {rd }}$ talks, 1984: 9-11.

${ }^{23}$ Rathgen, K. Kleine Beitrage zur Geschichte der Technik. Chemiker-Zeitung, 45, 1929: 1101.

${ }^{24}$ Pfister, Les Textiles du Tombeau de Toutenkhamon: 209.

${ }^{25}$ Petrie, W. M. The arts and Crafts of Ancient Egypt. Edinburgh and London, 1909, fig. 14; Wouters, J., Maes, L. and Germer, R. The Identification of Hematite as a Red Colorant on an Egyptian Textile from the Second Millennium B.C. in: International Institute for Conservation of Historic, Vol. 35, 1990: 89-92.

${ }^{26}$ Volger, H. The Craft of Dyeing in Ancient Egypt. Textile History, 13(2), Taylor \& Francis, 2013: 159-163.

${ }^{27}$ Lucas, A. Ancient Egyptian Materials and Industries. London, 1948: 61.

${ }^{28}$ Forbes, Studies in Ancient Technology: 110.

${ }^{29}$ Forbes, Studies in Ancient Technology: 111.

${ }^{30}$ Kendrick, A. F. The Textiles of Egypt. BMC, 48, 1962: 284-290. 
Ancient Egyptians used pomegranate peel or safflower, after it melts in water, to extract yellow color. Ocher, water iron oxide, was also used to get the range of yellow to brown colors since the Old Kingdom ${ }^{31}$.

Also, the art of dyeing before the New Kingdom was practiced by the fuller or the laundryman. In the New kingdom, dyer emerged as a further specialization and was entitled ps- insD, the "boiler of red cloth" 32 .

Apparently, the pieces investigated presented coloring techniques or dyeing treatments. It includes many colors including:

- Piece 71: reddish brown, light blue, yellow, and black pigmentation.

- Pieces 81-82: light blue, blue, red, light yellow, brown, and black pigmentation.

\section{Religious Significance of the Pieces Decorations \\ Piece no.71}

The piece no.71 is now displayed in hall no.3, the Pharaonic section at the basement of the Textile Museum. It is a square piece measuring L: $20 \mathrm{~cm}$ and $\mathrm{W}: 20 \mathrm{~cm}$. The piece is in a good condition of preservation due to the scientific restoration that carried out on it. It was discovered at relics of Deir El-Madineh in Luxor beside the Greco-Roman Temple and can be dated to the Ramesside Period, the reign of the Ramesses III, the second king of the $20^{\text {th }}$ Dynasty ( $\mathrm{ca}$. 1186$1155 \mathrm{BC})$ due to the style of iconography including slim human representation, cloths style, and hair wig style.

The main scene depicts a man called $N(y) s w$ pr and his wife $N \underline{d} m t$ presenting offerings and worshipping $\underline{t} 3-w r t^{33}$. Leitz translated her name as "=Die Grosse" 34 , "the Great (female) One". She stands on a low pedestal in her chapel surmounted by the usual $h k r w$ signs. As a protective deity, her iconography is terrifying with as it composes of the physical features of the pregnant hippopotamus (head and body), crocodile (back and tail), lion (hands and feet), and sagging human female breasts, and with open mouth and exposed tongue and tusks ${ }^{35}$. She is wearing a horned solar disk crown, worn by Isis and Hathor as she is performing a ritual ${ }^{36}$. She often sets her hand on the $s 3$ sign which means "protection" 37 but the sign is not depicted our scene. She used also to hold other magical objects such as wands, knives, children's feeding cups ${ }^{38}$.

Since the Predynastic period, male hippopotami were thought by ancient Egyptians as the representation of chaos $^{39}$; while females were the symbol of protection as they persistently protect the young hippopotami ${ }^{40}$. The female hippopotamus Taweret was worshipped throughout

${ }^{31}$ Gulragani, M. L. Introduction to Natural Dyes. Indian Institute of Technology, New Delhi, 1992: 9.

32 Pfister, R. Teinture et Alchemie dans l'Orient Hellenistique. Seminarium Kondakovianum, VII, 1935: 1-59; Schweppe, H. Identification of dyes in historic textile materials. Advances in Chemistry, 212, Washington DC, 1986: 153-174.

${ }^{33} \mathrm{~Wb}$, I: 330.

${ }^{34}$ Leitz, Ch. Lexikon der Ägyptischen Götter und Götterbezeichnungen. Brand VII, Peeters Publishers \& Department of Oriental Studies, Belgium, 2002: 331-2.

${ }^{35}$ Gundlach, R. Thoeris. In: Lexikon der Ägyptologie 6, Wiesbaden, 1985: 494-497; Verner, M. A Statue of Twert (Cairo Museum no. 39145) Dedicated by Pabesi and Several Remarks on the Role of the Hippopotamus Goddess. ZÄS 96, 1969: 61 .

${ }^{36}$ Leitz, Lexikon der Ägyptischen Götter: 331.

${ }^{37}$ Pinch, G. Magic in Ancient Egypt. British Museum Press, London, 1994: 39.

${ }^{38}$ Chamberlain, G. Historical perspectives on health: childbirth in ancient Egypt. The Journal of the Royal Society for the Promotion of Health 124 (6), 2004: 284-286; Ritner, R. Household Religion in Ancient Egypt. in: Household and Family Religion in Antiquity, J., Bodel and S.M., Olyan (eds.), Blackwell Publishing Ltd, Oxford, 2008: 177-178.

${ }^{39}$ Verner, A Statue of Twert: 53.

${ }^{40}$ Germond, P., and Livet, J. An Egyptian Bestiary. Thames and Hudson, London, 2001. 
Egypt as the goddess of childbirth and fertility. She was a pivotal deity in the daily religious life of Egyptian families. As the goddess of fertility and birth, pregnant and nursing females used to have amulets in the shape of Taweret to protect themselves and their infants from evil spirits ${ }^{41}$. Taweret was also identified with the female Hippopotami protective household goddesses such as Ipet $^{42}$, Reret, and Hedjet ${ }^{43}$.

Beside her pivotal role as the goddess of child rearing, she became also a funerary deity since the Middle Kingdom. In tombs and temples, it was a common practice to place hippopotamus statuettes adorned with marsh plants. According to some scholars, this is meant to facilitate the successful rebirth of the deceased into the afterlife by the hippopotamus goddess, just as she helped in earthly births ${ }^{44}$.

Figure 2: The Scene on the Piece 71

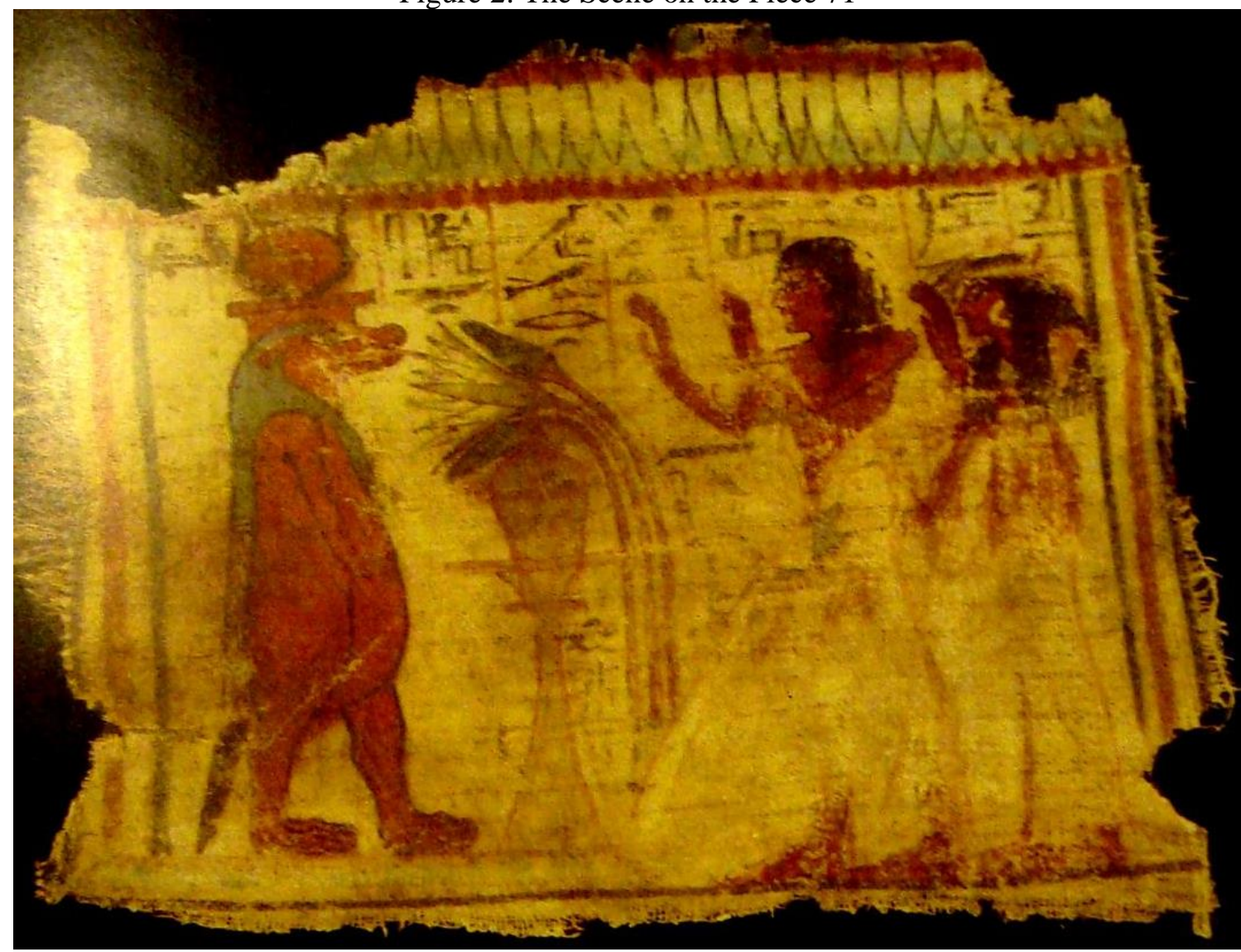

In the New Kingdom, this role of Taweret as a funerary deity was emphasized and reinforced in facilitating the passing of the deceased into the afterlife, nurturing and purifying him $^{45}$. This is obvious from her titles which informs her relationship with the sky, such as "Lady of Heaven" and "Mistress of the Horizon"; with water (for purification and nurturing), such as "She Who Removes Water", "Mistress of Pure Water"; and with giving birth, such as "Lady of the Birth

${ }^{41}$ Wegner, J. H. Taweret. In Redford, D. B. (ed) The Oxford encyclopedia of ancient Egypt. New York: Oxford: Oxford University Press, 2001:77-78; Robins, G. Women and children in peril: pregnancy, birth and infant mortality in ancient Egypt. KMT 5 (4), 1994-1995: 24-35.

${ }^{42}$ See Spell no. 269 in the Pyramid Texts - Allen, J. The Ancient Egyptian Pyramid Texts. Society of Biblical Literature, Atlanta, 2005: 49.

${ }^{43}$ Houser-Wegner, Taweret: 351-352; Robins, Women and children in peril: 29.

${ }^{44}$ Pinch, Magic in Ancient Egypt: 142.

${ }^{45}$ Pinch, Magic in Ancient Egypt: 142. 
House" ${ }^{\text {"46 }}$. Also, her title here $n b t{ }^{3}{ }^{C} t$ "Lady of truth" reflects her importance in helping $N(y) s w$ $p r$ and $N \underline{d} m t$ in their rebirth in the afterlife (see fig.2).

A hieroglyphic text in parallel rows was added in the upper part of the scene and reads:

The text before the head of Taweret:

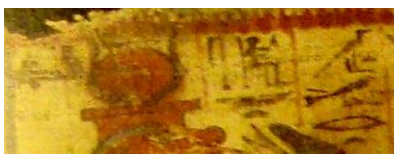

ț-wrt špsyt nbt $m 3{ }^{\complement} t$

The noble Taweret, Lady of truth

The word at the back of Taweret's crown is difficult to read. I suggest reading it as $m 3^{\complement} t$. Therefore, the composition $n b t m^{\top}{ }^{\top} t$ means the "Lady of Truth". It reflects the importance of Taweret at Deir El-Madina where the piece was discovered. The artisan village - flourished in the New Kingdom ( $c a .1550$ - 1080 BC.) - was called st $m 3{ }^{2} t$ "the place of truth" 47 .

The morphology of the sign m shows an odd direction contrary to the rest of word $m 3^{\top} t$ and to the direction of the whole phrase $\underline{t} 3$-wrt špsyt nbt.

While the first column of the man's name is illegible, I suggest that the second column reads:

The text above the head of the man:

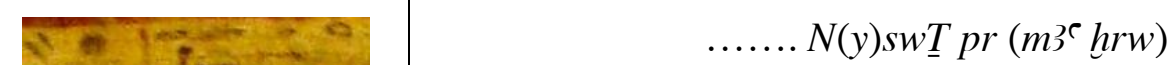

Who belongs to the house

$* N(y) s w^{48}$ (sign no. m23).

Above the woman's head, her name reads:

The text above the head of the women:

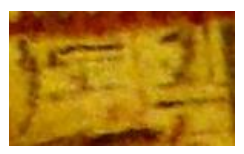

$N \underline{d} m t m 3^{e} h r w$

Nedjmet, justified

The sign (m29) represents a pod from a sweet smelling tree and reads $n \underline{d} m^{49}$. The name $N \underline{d} m t$ exist as a personal name since the Middle Kingdom and continued to be used till the New Kingdom $^{50}$.

${ }^{46}$ Houser-Wegner, J. Taweret. In: The Ancient Gods Speak: A Guide to Egyptian Religion. D. Redford(ed.), Oxford University Press, Oxford, 2002: 351-352.

${ }^{47}$ Lesko, L.H. (Ed.). Pharaoh's Workers: The Villagers of Deir El-Madina. Cornell University Press, 1994: 7; Oaks, I. The Illustrated Encyclopedia of Pyramids, Temples, and Tombs of Ancient Egypt. South water, 2006:110.

48 See Gardiner, A.H., Egyptian Grammar. Being an Introduction to the Study of Hieroglyphs, 1 ${ }^{\mathrm{ed}}$, London, 1927: 482.

${ }^{49}$ Gardiner, Egyptian Grammar: 483.

50 Ranke, H., Die Ägyptischen Personnennamen, Band I, Glückstadt, 1935: 215 (24); for the Middle Kingdom examples see one piece among the Egyptian collection in the Louvre Museum: Boreux, Ch. Antiquités Egytiennes Catal-Guide, Musee du Louvre, Paris, 1932: C171; Catalogue general des Antiquités égyptienne du Musée du Caire. Inventory number $(20190 \mathrm{~K})$; Holwerde, A. E. J. et al. Beschrijving van de Egyptische verzameling in het Rijksmuseum van oudheden te Leiden, deel.V, Leiden und s'Gravenhage, 1905-1932: 103. Also for the New Kingdom examples see: Memoires Publies par les members de la mission archéologiques Française du Caire, Tome Iff., Paris, 1889-1890: 8, 293, 226; British Museum, A Guide to the Fourth, Fifth, and Sixth Egyptian Rooms, and the Coptic Room. London, 1922: 303; Boreux, Ch. Antiquités Egytiennes Catal-Guide, Musée du Louvre, Paris, 1932: C80. 


\section{Pieces nos.81-82}

The other two pieces (nos.81\&82) are now displayed in hall no.1, the Pharaonic section at the basement of the Textile Museum. The two pieces are rectangular in shape measuring L: $9 \mathrm{~cm}$ and $\mathrm{W}: 3.5 \mathrm{~cm}$. They are in bad conditions due to several reasons including: the loss of most of their parts; the shabby ends; the pale dyes; the loss of humidity content which affected textile elasticity and caused drought which, in turn leads to fragility; and finally the effect of bad storage before being exhibited in the Textile Museum. They were discovered in the tomb of Thutmosis IV in Luxor, and bear his titles.

The decorations form vertical hieroglyphic texts on the two pieces and read:

S3 mry.f $n b h^{\complement} w$ `h3(.w) $r$ hfnw
His beloved son, lord of glory, who fights against hundreds
of thousands"

The hieroglyphic text on the piece 81 reflects an important funerary significance. The title $s 3$ $m r y=f$ used to be taken by Horus (the son) who is assigned to perform the "Opening of the Mouth" ceremony (wp-r ${ }^{51}$ ) to Osiris the King (his deceased father or grandfather) so that he could breathe and talk, as emphasized in many instances in the Pyramid texts ${ }^{52}$. The ancient Egyptians believed that this ceremony will help the soul to nourish in the afterlife. This means that Thutmosis IV, who was entitled $s 3 m r y=f$, was the one who has done this ceremony for his grandfather Thutmosis III whose Horus name $h r k 3 n h t h^{\complement} m[W 3 s t]$ is written here ${ }^{53}$.

\section{Discussion and Conclusion}

Three ancient Egyptian decorated textile pieces, preserved in the 'Egyptian Textile Museum', were investigated in this study from both morphological and religious sides. Technical setting about the techniques of the fabric decoration is delivered using visual examination of

${ }^{51} \mathrm{~Wb}, \mathrm{I}: 300$.

52 Pyr. 2221b; Pyr. 1331a-b; Pyr. 179a-b; Pyr.626a.

${ }^{53}$ Beckerath, J. Handbuch der ägyptischen Königsnamen. Teil. III, München, Berlin, Deutscher Kunstverlag, 1984: 226. 
decorations' fibers by light microscope. Results revealed that they would have been made out of linen in vertical loom, the yarns correspond to S-twisted ends, with a strong degree of torsion and fine thickness with varied density. The decoration technique used is tapestry plain weave and coloring.

The religious significance of the decorations - in the form of scenes and texts - was also analyzed and brought into argumentation. The scene on piece no.71 is considered one of the rarest examples of Taweret representation on textile. It highlights her role as a funerary deity as she facilitates the successful passing of the deceased into the afterlife, just as she helped in earthly births, beside nurturing and purifying him/her. In the accompanied text, she bore the title $n b t m^{3} t$ "Lady of truth" which emphasizes: I) her importance in helping the man $N(y) s w p r$ and the lady $N \underline{d m t}$ in their rebirth in the afterlife; II) the importance of Taweret at Deir El-Madina - st $m 3^{\mathrm{C}} t$ "the place of truth" - where the piece was discovered.

The texts on pieces nos.81-82 are correlated and also reflect an important funerary significance especially that the title $s 3 m r y=f$ (piece 81 ) mentioned in many instances in the Pyramid texts in the context of Horus (the son) who performs the "Opening of the Mouth" ceremony (wp-r) to Osiris the King (his deceased father or grandfather). Therefore, Thutmosis IV here was entitled $s 3$ $m r y=f$, was the one who has done this ceremony for his grandfather Thutmosis III whose Horus name $h r k 3 n h t h^{\ulcorner} m[W 3 s t]$ is written on the piece no.82.

\section{Acknowledgements}

The researcher presents his gratitude to the Egyptian Textile Museum administration who allows photographing the three pieces under investigation and provided very useful information and samples. Also, warm thanks to Dr. Tamer Magdi who presented very useful insights based on his background in ancient textile research, and Dr. Neven Fahim who did the visual examination of fibers by light microscope.

\section{References}

Allen, J. The Ancient Egyptian Pyramid Texts. Society of Biblical Literature, Atlanta, 2005.

Allgrove-Mcdowell, J. Industries of the Near East and Europe in prehistory, Ancient Egypt, 5000-332 BC. In David T. J. (Ed.), the Cambridge History of Western Textiles. United Kingdom: Cambridge University Press, (2003).

Barber, E.J.W. New Kingdom Egyptian Textile: Embroidery V.S Weaving. AJA 86, 1982: 442445.

Barber, E. Prehistoric Textiles. Princeton: Princeton University Press, 1991.

Beckerath, J. Handbuch der agyptischen Königsnamen. Teil. III, München, Berlin, Deutscher Kunstverlag, 1984.

Bellinger, L. and Batigne, R. The Significance and Technical Analysis of Ancient Textiles as Historical Documents. PAPS, 97, 1953: 670-680.

Bellinger, L. Textile Analysis: Developing Techniques in Egypt and Near East. vol.IV, Washington, 1957.

Boreux, Ch. Antiquités Egytiennes Catal-Guide, Musée du Louvre, Paris, 1932.

British Museum, a Guide to the Fourth, Fifth, and Sixth Egyptian Rooms, and the Coptic Room. London, 1922.

Chamberlain, G. Historical perspectives on health: childbirth in ancient Egypt. The Journal of the Royal Society for the Promotion of Health 124 (6), 2004: 284-286.

Crowfoot, G.M., Textiles, Basketry and Mats: A history of Technology, I. Oxford, 2001.

Depas, S. Weaving and Tapestry Art in fiber. Macmillan publish Go, INC, New York, 1989.

Emery, I. The primary structures of fabrics. An Illustrated Classification. Washington, D.C.: Watson-Guptill Publications, Whitney Library of Design, The Textile Museum, 1995. 
Eric, B. The Book of Looms. New York, 1998.

Erman, A. \& Grapow, H. Wörterbuch der Ägyptischen Sprache. 5 vols, Berlin, 1926-1931.

Fischer, H. G. Egyptian women of the old kingdom. And of the Heracleopolitan Period. New York: The Metropolitan Museum of Art, 2000.

Forbes, R. J. Studies in Ancient Technology. vol.IV, Leiden, 1956.

Gardiner, A.H., Egyptian Grammar. Being an Introduction to the Study of Hieroglyphs, $1^{\mathrm{ed}}$, London, 1927.

Germond, P., and Livet, J. An Egyptian Bestiary. Thames and Hudson, London, 2001.

Gulragani, M. L. Introduction to Natural Dyes. Indian Institute of Technology, New Delhi, 1992.

Gundlach, R. Thoeris. In: Lexikon der Ägyptologie, 6, Wiesbaden, 1985: 494-497.

Hall, R. Egyptian textiles. United Kingdom: Shire Publications LTD, 2001.

Harries, J. 5000 years of Textile. British Museum, London, 2004.

Hilary, C. Simple Weaving. Studio vista, London, 1973.

Holwerde, A. E. J. et al. Beschrijving van de Egyptische verzameling in het Rijksmuseum van oudheden te Leiden, deel.V, Leiden und s'Gravenhage, 1905-1932.

Houser-Wegner, J. Taweret. In: The Ancient Gods Speak: A Guide to Egyptian Religion. D. Redford (ed.), Oxford University Press, Oxford, 2002.

Hubner, J. The Examination of Some Ancient Egyptian Textiles, Journal of the Society of Dyers and Colouris, 25, 1909: 223-226.

Kendrick, A. F. The Textiles of Egypt. BMC, 48, 1962: 284-290.

Kourkoumelis, N. Physicochemical Characterization of Thermally Aged Egyptian Linen Dyed with Organic Natural Dyestuffs. Applied Physics, 112(2), 2013: 469-478.

Landi, S. The Textile Conservator's manual, London, 1985.

Leitz, Ch. Lexikon der Ägyptischen Götter und Götterbezeichnungen. Brand VII, Peeters Publishers \& Department of Oriental Studies, Belgium, 2002.

Lesko, L.H. (ed.). Pharaoh's Workers: The Villagers of Deir El-Madina. Cornell University Press, 1994.

Lucas, A. Ancient Egyptian Materials and Industries. London, 1948.

Memoires Publies par les members de la mission archéologiques Française du Caire, Tome Iff., Paris, 1889-1890.

Oaks, I. The Illustrated Encyclopedia of Pyramids, Temples, and Tombs of Ancient Egypt. Southwater, 2006.

Petrie, W. M. The arts and Crafts of Ancient Egypt. Edinburgh and London, 1909.

Pfister, R. Les Textiles du Tombeau de Tutankhamen. in: Revue des Arts Asiatiques II, 1937: 207-218.

Pfister, R. Teinture et Alchemie dans l'Orient Hellenistique. Seminarium Kondakovianum, VII, 1935: 1-59.

Pinch, G. Magic in Ancient Egypt. British Museum Press, London, 1994.

Ranke, H., Die Ägyptischen Personnennamen, Band I, Glückstadt, 1935.

Rathgen, K. Kleine Beitrage zur Geschichte der Technik. Chemiker-Zeitung, 45, 1929.

Ritner, R. Household Religion in Ancient Egypt. in: Household and Family Religion in Antiquity, J., Bodel and S.M., Olyan (eds.), Blackwell Publishing Ltd, Oxford, 2008: 177-178.

Robins, G. Women and children in peril: pregnancy, birth and infant mortality in ancient Egypt. KMT 5 (4), 1994-1995: 24-35.

Russell, C. K. Tapestry Handbook. Schiffer Publication Ltd, 2007.

Salmon, L. Textiles: Egypt's Golden age, the Art of Living in the New kingdom. Museum of fine art, Boston, 1982. 
Schweppe, H. Identification of dyes in historic textile materials. Advances in Chemistry, 212, Washington DC, 1986: 153-174.

Thompson G.W. History of Tapestry from earliest until the present day. New York, 1977.

Verner, M. A Statue of Twert (Cairo Museum no. 39145) Dedicated by Pabesi and Several Remarks on the Role of the Hippopotamus Goddess. Z̈̈S 96, 1969: 61.

Vogelsang-Eastwood, G. Egyptian Dyes and Colors. In: Dyes on historical and archaeological Textiles, Summery of $3^{\text {rd }}$ talks, 1984: 9-11.

Vogelsang-Eastwood, G. Textiles: Ancient Egyptian Materials and Technology. In Paul T. Nicholson \& Ian Shaw (Eds.), United Kingdom: Cambridge University Press, 2000.

Volger, H. The Craft of Dyeing in Ancient Egypt. Textile History, 13(2), Taylor \& Francis, 2013: 159-163.

Wegner, J. H. Taweret. In Redford, D. B. (Ed) The Oxford encyclopedia of ancient Egypt. New York: Oxford: Oxford University Press, 2001: 77-78.

Wouters, J., Maes, L. and Germer, R. The Identification of Hematite as a Red Colorant on an Egyptian Textile from the Second Millennium B.C. in: International Institute for Conservation of Historic, vol. 35, 1990: 89-92.

Yvonne, H. Decoration in Egyptian Tombs of the Old Kingdom, London, 1987. 